\title{
Analysis of User Perceptions of Transport Service Performance in Makassar City
}

\author{
Didin Halim, Herman $\mathbf{H}$ \\ Ilmu Administrasi Negara, Universitas Negeri Makassar \\ Email: didinhalim68@gmail.com, hermandody@unm.ac.id
}

(Received: December 12-2019; revised: February 15-2020; published: June 31-2020)

\begin{abstract}
Changes in the arrangement of transportation system services in Makassar City must be made immediately in realizing public transportation systems that meet the expectations and needs of the community. There are problems with the performance of Pete-Pete's public transport services in terms of reliability, comfort, security, generosity, and timeliness of pete-pete public transport in Makassar City. The purpose of this study is to analyze the description of users' perceptions of public transport and examine the effect of reliability, comfort, security, generosity and timeliness on the performance of public transport in Makassar. This research uses a quantitative approach with data collection techniques through observation, questionnaires and in-depth interviews and documentation studies. The research sample of 150 people as respondents. This study uses SEM analysis with the SmartPLS package program ver. 2.0 ME, to estimate the model, study and test hypotheses. The results of this study indicate that (i) There is a positive influence on the reliability factor on the performance of Pete-Pete transportation in Makassar City, with a contribution of $44.30 \%$ (ii) There is a positive influence of comfort factor on the performance of Pete-Pete transportation in Makassar City, with the contribution of $26.35 \%$, (iii) There is no positive effect on the performance of the Pete-Pete transportation performance in Makassar City, with a contribution of only $0.78 \%$. (iv) There is a positive influence of the factor of mercy on the performance of Pete-Pete transportation in Makassar City, with a contribution of $54.23 \%$ and (v) There is a positive influence of the timeliness factor on the performance of Pete-Pete transportation in Makassar City, with a contribution of $60.50 \%$.
\end{abstract}

Keywords: User Perception; Transportation Service Performance; public transportation

\section{INTRODUCTION}

Public transportation as part of the urban transportation system is one of the basic needs of urban society and is an inseparable part of the needs of the city in general. This public transportation has a crucial role in serving urban transportation and makes it easy for the community to carry out its activities in all different locations and spread in the Makassar City area. The existence of public transportation is very needed, especially for people who do not have private transportation.

In Makassar City, public transportation is called "pete-pete". Considering its important role in serving users, Pete Pete is an alternative to public transportation that serves many public passengers. However, its existence has many problems in serving transport users, including, less comfortable, reckless driver, careless stop and less concerned about the safety of passengers. This problem, if not handled properly and properly, will be a major problem for the life of urban transportation. 
The perception of users of public transportation basically requires an adequate level of service, both travel time, waiting time and guaranteed safety and comfort during the trip. If public transportation cannot meet the needs of urban transportation for the community and the facilities offered are inadequate in providing services to its users, there will be a tendency to leave the mode of transportation. This has an impact on increasing the level of private vehicle ownership which can lead to many traffic problems such as traffic jams, parking problems, increased pollution, increased accident rates and so on.

This phenomenon is often found in using passenger public transportation at present. The performance of transportation services is getting worse and worse, both in terms of transportation comfort, safety and reliability. Besides that, the driver's behavioral aspects in traffic that tend to have a negative impact on other road users, and lead to lower service performance.

This condition, can also be suspected as a result of the weakness of the management system, which institutionally applies the deregulation model, which is a model in which the implementation of urban transportation is the position of the Government (the City) as the policy maker (system planner) and at the same time as the licensor of its implementation, do not conduct regulations / good monitoring of the operation of pete-pete transport services proportionally in Makassar City.

Based on the problems that have been raised then in this study the problem was formulated namely 1). What is the description of user perceptions of public transportation in Makassar City? 2). Is there an influence of reliability, comfort, security, generosity and timeliness on the performance of public transport in Makassar City?

The benefits obtained from the study of the performance assessment of public transport services are taken into consideration for relevant agencies further to improve public transport operation services in Makassar City. Material for consideration in making transportation decisions (policies) in favor of the user community in Makassar City.

\section{METHOD}

This research is a quantitative descriptive study using a survey approach. The quantitative descriptive research was chosen, that is, a study that took a sample from one population using a questionnaire as the main data collector, to obtain factual information and facts or phenomenon explanation, and in general the unit of analysis was individuals in this case were users of petepete transportation services. in Makassar City.

This research was conducted in January-March 2020 with a focus on the disclosure of the causal relationship between the variables of the causal relationship between variables and their effect on other variables. The variables of this study are the perception of service users and the performance of public transport services in Makassar City.

Research Locations This research was conducted in Makassar City, at three different locations, including 1). Rute Makassar Mall - UNM -Perumnas Panakukang is managed by the company CV. Joint Rojali, 2). Route Makassar Mall - Pa'baeng-baeng- Perumnas Panakukang is managed by the company CV. Koharja and, 3) Malengkeri-Cendrawasih Terminal Route Unhas Campus, managed by the company CV. Your sister the number of respondents was 150 
people, especially users of public transportation with the type of microbus transportation (angkot pete pete).

The definition of service user perception is a response to the knowledge and experience of individuals in responding to the performance of transportation services, including the dimensions of reliability, comfort, security, cheap and timely travel. The performance of transportation services is the level of achieving optimal results in order to realize the objectives of the transport company as measured by the dimensions of reliability (physical evidence), dimensions of reliability (reliability), dimensions of responsiveness (responsiveness), dimensions of assurance (assurance) and dimensions of empathy (attention), as perceived by service users.

The main data collection technique is a questionnaire. This technique is used to obtain variable data on service user perceptions about reliability, comfort, safety, generosity, timely and performance. The questionnaire technique was made in the form of closed questions totaling 70 numbers. Each item of question or statement is complemented by five tiered alternative choices of answers that describe the respondents' level of agreement and rejection of the item submitted. The format of the answers for each questionnaire is a Likert type.

The data is processed by a factor analysis method using the SmartPLS software package ver. 2.0 ME The method of analysis between user perception and service performance (Importance Performance Analysis), as well as an overview of user perceptions of the performance of pete-pete transport services in Makassar City.

\section{RESULT AND DISCUSSION}

User analysis of Pete-Pete Transportation can be measured in terms of reliability, comfort, safety, cheap and timely Pete-Pete transportation.

\section{Reliability aspects}

The aspect of reliability can be measured from the presence of pete-pete at any time available based on the purpose of the trip, arrival and until the destination on time, the total time of a short trip from home, less time walking to the bus stop, no need to change vehicles.

Based on the purpose of the trip, the majority of respondents i.e. $42 \%$ of respondents use Pete-Pete Transportation from / to school or campus. There is a difference of $14.67 \%$ with the aim to / from work. So that the use of Pete-Pete Transportation to carry out routine activities every day is $76.7 \%$ considered constant for each day. Whereas for other purposes $23.33 \%$ use of Pete-Pete Transport is only for certain times.

In general, the travel time of Pete-Pete Transportation in traveling to their destination, it is known that $56.67 \%$ is $6-10$ minutes each way. This applies at normal times, freezing or other interruptions. The community prefers to use Pete-Pete Transportation by reason of the short Pete-Pete Transport travel time to reach their destination, without the need to wait for other passengers. Community activities that demand fast means of transportation cause a tendency to choose this mode of transportation compared to other public transportation.

The results of the study showed that the distance of Pete-Pete Transport in traveling to and from its destination was $62.67 \%$ with a distance of more than $10 \mathrm{Km}$. Most people use the 
278 Jurnal Ilmiah Ilmu Administrasi Publik: Jurnal Pemikiran dan Penelitian Administrasi Publik

Volume 10 Number 1, January - June 2020. Page 275-286

Pete-Pete Transport for the purpose of going to school / campus or to the workplace, and office locations and educational centers are located in the city center. People who live in the city of Makassar in particular the location of the study, generally travel using Pete-Pete Transportation with a considerable distance.

\section{Comfort}

Convenience is a condition that is felt by users of Pete-Pete Transport when traveling is measured by the intensity of its use, the ease of obtaining transportation and the smoothness of transportation. The results showed that there were 54\% always using this transportation while traveling and $35 \%$ often using pete-pete transportation, while $10 \%$ who stated sometimes using pete-pete transport. It's just that during rainy weather conditions usually cause discomfort for Pete-Pete Transport users in their use. This is due to the improper construction of Pete-Pete Transportation such as rain water that easily enters Pete-Pete Transport and incomplete bus equipment.

Judging from the level of ease of obtaining Pete-Pete Transportation, 54\% of respondents choose it is very easy to get Pete-Pete Transportation because the distance from one place to the Pete-Pete Transportation Base is only $<100 \mathrm{~m}$. This is due to the presence of Pete-Pete Transportation which always crosses city center roads, as well as on environmental roads because Pete-Pete Transport is the main means of transportation used by the people of Makassar, so Pete-Pete Transportation is very easy to reach by users without having to waited a long time and traveled a considerable distance.

Based on the smoothness of the trip, as many as $62 \%$ of respondents chose very smoothly and only $6.67 \%$ stated it was not smooth when traveling using Pete-Pete Transportation. User perception states that in general experienced drivers on the highway also rarely experience problems with the traffic police during the trip.

\section{Safety Aspects}

Safety is the level of security when using Pete-Pete Transportation measured by the level of safety in travel and accident rates as well as the level of fatality experienced by users of the Pete-Pete Transport mode. Based on the level of safety in the trip of $56.67 \%$ of respondents said it was safe to use Pete-Pete Transportation because most of the passengers had never been injured in their use. As many as $62.00 \%$ or generally say that it is very smooth from the level of fatality caused by Pete-Pete Transportation. This shows that the accident rate caused by PetePete Transport tends to be smaller than other transportation, so Pete-Pete Transport is much in demand by the user community.

\section{The Urbanity aspect}

In the variable of generosity related to the tariff or fee charged by the user. Fare is the amount of travel costs charged to Pete-Pete Transport service users which is measured based on travel rates (Rupiah / one way). That based on travel rates, it is known that $80 \%$ of Pete-Pete Transport fares are around Rp. The remaining 5,000 are only $16.67 \%$ for students. The tariff 
setting determined by the Makassar City Government is basically a standard tariff and has generally been followed by the Mayor's policy as well as Rp.5,000 each time riding pete-pete transportation. However, in general the determination of Pete-Pete Transport fares is determined by bargaining between passengers and drivers based on distance traveled (kilometers). The longer the distance traveled, the higher the fare that must be paid. This shows that respondents traveled a considerable distance per one way.

\section{Timeliness Aspect}

Based on the results of the study showed that perceptions of pete-pete transport users on punctuality both when riding a vehicle up to the destination of travel generally stated on time that there were $63.33 \%$, while those who stated not on time were $6.67 \%$, less precise $8.67 \%$, and very timely $21.33 \%$. Furthermore, to test the effect of perceptions of public transport users on the performance of pete-pete public transport services in the city of Makassar, a statistical analysis of the SEM test was performed with the help of SmartPLS 2.0 M3 software based on certain steps and prerequisites.

Based on the research results obtained that the data with endogenous latent variables are the performance of transportation which is measured through exogenous latent variables namely Reliability, Comfort, Safety, Welfare, and Timeliness. The five variables each have indicators that influence it. For testing the measurement model (outer model) is done by seeing whether the value of the loading factor indicator meets convergent validity. To meet the convergent validity value, the loading factor value must be $>0.50$. If the loading factor is $<0.50$ then the indicator must be dropped from the analysis because it will indicate that the indicator is not good enough to measure the latent variable precisely. After the indicator that does not meet the convergent validity value is dropped, the data is reprocessed to meet the convergent validity.

The convergence validity of each indicator for each latent variable is as follows:

a. Reliability Variable

Reliability is a latent variable measured by seven indicators for this variable, namely $\mathrm{X} 11, \mathrm{X} 12, \mathrm{X} 13, \mathrm{X} 14, \mathrm{X} 15, \mathrm{X} 16, \mathrm{X} 17$. The test results in the outer loading table (measurement model), show that the value of the loding factor on the five indicators can be checked with the criteria that it is said to be valid if the loding value is> 0.5 . From the seven indicators, the results obtained for X11, X13, X14 and X16 have a loading value $<0.5$. while for variables $\mathrm{X} 12, \mathrm{X} 15$, and $\mathrm{X} 17$, it has a loading value $>0.5$. Thus, there are four indicators in Reliability that must be dropped namely X11, X13, X14 and X16

b. Convenience Variable

Convenience is a latent variable measured by seven indicators for this variable, namely $\mathrm{X} 21, \mathrm{X} 22, \mathrm{X} 23, \mathrm{X} 24, \mathrm{X} 25, \mathrm{X} 26$ and X27. The results of the test in the outer loading table (measurement model), show that the value of the loding factor on the seven indicators can be checked with the criteria that it is said to be valid if the loding value is> 0.5 . From the seven indicators obtained for each result, X23, X25 has a loading value $<0.5$ while for the variables X21, X22, X23, X24, X26 and X27 have a loading value > 0.5. Thus, the indicator in Comfort that must be dropped is X25

c. Security Variable

Security is a latent variable measured by seven indicators for this variable, namely $\mathrm{X} 31$, X32, X33, X34, X35, X36 and X37. The results of the test in the outer loading table 
280 Jurnal Ilmiah Ilmu Administrasi Publik: Jurnal Pemikiran dan Penelitian Administrasi Publik

Volume 10 Number 1, January - June 2020. Page 275-286

(measurement model), show that the value of the loding factor on the seven indicators can be checked with the criteria that it is said to be valid if the loding value is $>0.5$. From the seven indicator variables, the results obtained for X31, X36 and X37 respectively have loading values $>0.5$. Thus, the indicators in Security that must be dropped are X32, X33, X34, X35

d. Welfare Variable

Kelurahan is a latent variable measured by seven indicators for this variable, namely X41, X42, X43, X44, X45, X46 and X 47. The results of the test in the outer loading table (measurement model), indicate that the magnitude of the loding factor on the seven indicators can be checked with the criteria that is said to be valid if the value of lodging is $>0.5$. From the seven indicators, the results obtained for X41, X42, X44, X46 have a loading value $>0.5$. whereas for variables $\mathrm{X} 43, \mathrm{X} 45, \mathrm{X} 47$ have a loading value $<0.5$. Thus, the indicator variable of Village that must be dropped is X43, X45, X47.

e. Timely Variable

Timeliness is a latent variable measured by seven indicators for this variable, namely X51, X52, X53, X54, X55, X56 and X57. The test results in the outer loading table (measurement model), show that the value of the loding factor on the seven indicators can be checked with the criteria that it is said to be valid if the loding value is $>0.5$. From the seven indicator variables, the results obtained for X52, X53, X56 have loading values> 0.5. Thus, indicators in the timeliness variable that must be dropped are X51, X54, X55, and X57.

f. Transportation Performance Variable

Transportation performance is a latent variable measured by thirty-five indicators for this variable, namely Y11, Y12, Y13, ..., Y17, and Y21, Y22, Y23, ..., Y27, and Y31, Y32, Y $33, \ldots$, Y 37 , and Y $41, \mathrm{Y} 42, \mathrm{Y} 43, \ldots . .$. Y $47, \mathrm{Y} 51, \mathrm{Y} 52, \mathrm{Y} 43, \ldots \ldots$. Y 57. The test results in the outer loading table (measurement model), show that the value of the loding factor in the thirty-five indicators can be checked with the criteria that it is said to be valid if the loding value is $>0.5$. From all the performance indicators obtained results are Y16, Y17, Y24, Y25, Y26, Y27, Y31, Y42, Y43, Y45, Y51, Y54, Y55, Y55, and Y57, because they have loading values $>0.5$. As for the other indicators, the loading value is $<0.5$ and must be dropped.

The construct indicator correlation has a higher value compared to the correlation indicator for other constructs. Thus it can be concluded that the indicators of each construct give a high convergent validity value, all>0.50. Likewise the cross loading value shows good discriminant validity.

Reliability test in PLS is done by looking at the composite reliability value of the indicator block that measures the construct. The composite reliability results will show a satisfactory value if above 0.7 . It shows that the composite reliability value for all constructs is greater than 0.7 which shows that all constructs in the estimated model have high reliability and meet the reliable criteria.

This structure shows exogenous variables, namely (Performance), as well as five endogenous variables, namely (Reliability), (Comfort), (Security), (Kelurahan) (Timeliness). 
The value of the path coefficient indicates the influence of the variable (Reliability) to (Comfort), the value of the path coefficient indicates the influence of the variable (Performance) to (Security), the value of the path coefficient indicates the effect of the variable (Performance) on (Security), the value of the path coefficient indicates the influence variable (Performance) to (Kelurahan), the path coefficient value indicates the influence of the variable (Performance) on (Timeliness). The value indicates the influence of other variables besides, on the variable.

To estimate the parameters of the model, the Partial Least Square (PLS) method is done through the smartPLS 2.0 statistical program. the results of the analysis are obtained as in Figure 1 below:

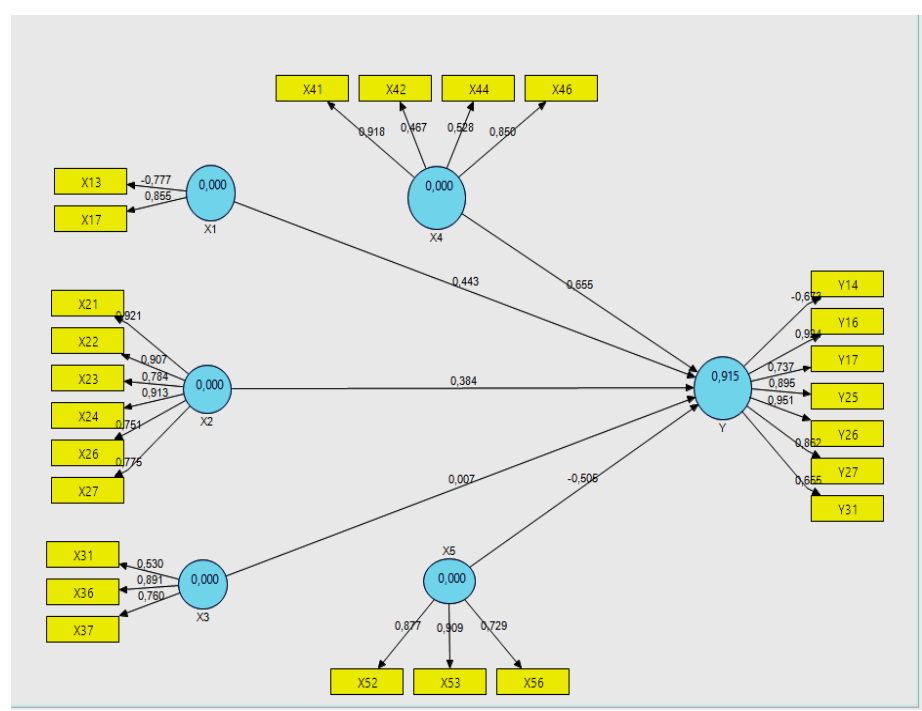

Figure 1

PLS Output Pathway Diagram with SmartPLS software.

\section{Hypothesis Testing Results}

Testing this hypothesis is based on processing research data using SmartPLS. With the boostrap resampling method, t-statistic values are obtained which will then be compared with $\mathrm{t}$ table values. If the $\mathrm{t}$-statistic value is greater than the t-table value, the proposed research hypothesis is accepted and vice versa. The level of confidence used is $95 \%$, so the inaccuracy limit is $(\alpha)=5 \%=0.05$ with a t-table value of 1.96 . So that:

If the $\mathrm{t}$-statistic value is smaller than the $\mathrm{t}$-table value [t-statistic <1.96], then Ho fails to reject.

If the t-statistic value is greater or equal to t-table [t-statistic $\geq 1.96$ ], then Ho is rejected.

Hypothesis testing for inner models is done by looking at $\mathrm{t}$-statistics on the results for inner weights as presented in the following table. 
282 Jurnal Ilmiah Ilmu Administrasi Publik: Jurnal Pemikiran dan Penelitian Administrasi Publik Volume 10 Number 1, January - June 2020. Page 275-286

Table 2

The results of testing the effect of exogenous latent variables on endogenous variables with SmartPLS software.

\begin{tabular}{|c|c|c|c|c|c|}
\hline & $\begin{array}{c}\text { Original } \\
\text { Sample (O) }\end{array}$ & $\begin{array}{c}\text { Sample } \\
\text { Mean (M) }\end{array}$ & $\begin{array}{c}\text { Standard } \\
\text { Deviation } \\
\text { (STDEV) }\end{array}$ & $\begin{array}{c}\text { Standard } \\
\text { Error } \\
\text { (STERR) }\end{array}$ & $\begin{array}{c}\text { T Statistics } \\
\text { (|O/STERR|) }\end{array}$ \\
\hline $\mathbf{X 1}$-> Y & 0,442532 & 0,448809 & 0,076668 & 0,076668 & 5,772053 \\
\hline $\mathbf{X 2}$-> Y & 0,383713 & 0,376236 & 0,145623 & 0,145623 & 2,634978 \\
\hline $\mathbf{X 3}$-> Y & 0,007083 & $-0,002409$ & 0,089667 & 0,089667 & 0,078996 \\
\hline $\mathbf{X 4}$-> Y & 0,654934 & 0,666403 & 0,120765 & 0,120765 & 5,423204 \\
\hline $\mathbf{X 5}$-> Y & 0,504587 & $-0,504035$ & 0,077614 & 0,077614 & 6,501269 \\
\hline
\end{tabular}

Based on Table 2, the results of hypothesis testing for the inner model are as follows:

\section{The first hypothesis}

Based on the results in Table 2, it appears that the Reliability variable has a positive effect on transportation performance with a parameter coefficient of 0.442532 with a statistical value $=5.772053>$ ttable $=1.96$. Because the value of tstatistik $>$ ttable then it can be said that $\mathrm{H} 0$ is rejected, in other words that there is a significant influence on the Reliability variable on Transportation Performance.

\section{The second hypothesis}

That the Comfort variable has a positive influence on the Transportation Performance with a parameter coefficient of 0.383713 with a statistical value $=2.634978>\mathrm{t}$ table $=1.96$. Because the value of tstatistik>ttable then it can be said that $\mathrm{H} 0$ is rejected, in other words that there is a significant influence on the comfort variable on Transportation Performance.

\section{Third hypothesis}

That the Safety variable has a positive influence on the Transportation Performance with a parameter coefficient of 0.007083 with a statistical value $=0.078996<$ ttable $=1.96$. Because the tstatistik value <ttable then it can be said that $\mathrm{H} 0$ failed to be rejected, in other words that there is no significant influence of the Security variable on Transportation Performance.

\section{The fourth hypothesis}

That the variable of Village has a positive influence on the Performance of Transportation with a parameter coefficient of 0.654934 with a statistical value $=5.423204 \mathrm{>}$ table $=1.96$. Because the value of tstatistik $>$ ttable then it can be said that $\mathrm{H} 0$ is rejected, in 
Didin Halim, Herman H; Analisis Persepsi Pengguna Terhadap Kinerja Pelayanan Angkutan ... | 283

other words that there is a significant influence of the variable of Village on Transportation Performance.

\section{The fifth hypothesis}

That the Timeliness variable has a positive effect on the Transportation Performance with a parameter coefficient of 0.504587 with a statistical value $=6.501269>$ ttable $=1.96$. Because the value of tstatistik> ttable then it can be said that $\mathrm{H} 0$ is rejected, in other words that there is a significant influence of the Timeliness variable on the Performance of Pete-Pete Transportation in Makassar City.

\section{Discussion}

Based on the research results obtained by the R-Square value of each model is for the endogen variable Reliability of 0.443 for the comfort endogen variable of 0.384 , for the security endogen variable of 0.007 , for the Endogen variable of Urbanity of 0.655 , and for the timeliness endurance variable of 0.508. As for the exogenous variable at 0.915 .

Based on the R-Square value, it can be calculated the predictive relevance Q2 value of each model with the formula is $\mathrm{Q} 2=1$ - (1- R2). So, for models with endogenous latent variables Reliability Q2 predictive relevance is 0.443 . For the endogen variable Comfort Q2 predictive relevance of 0.3384 . For the endogen variable Security Q2 predictive relevance of 0.007. For the endogen variable Subdistrict Q2 predictive relevance is 0.655 . For the endogen variable the timeliness of $\mathrm{Q} 2$ is predictive relevance of 0.508 . And endogenous latent variables Transport Performance Q2 predictive relevance of 0.915 .

Because the Q2 value is predictive relevance> 0, the model in this study has a good predictive relevance. Therefore, based on the Q2 value, it shows that the overall structural model in this study is quite significant.

Testing the hypothesis in Partial Least Square is to determine the effect of the five exogenous latent variables on endogenous latent variables. If the t-statistic value in the Path Coefficient table is greater than the t-table value, it can be said that the variable significantly influences the Transportation Performance, namely Reliability, Comfort, Security, Welfare and Timeliness.

Based on the results obtained in the third hypothesis, it cannot be supported because the $\mathrm{t}$-statistic value of the Safety variable on Transportation Performance is 0.007 smaller than the $\mathrm{t}$ table value (1.96) for $n=150$. As for the first, second, fourth and fifth hypotheses, it can be supported because the t-statistic value on the Reliability variable to the performance is 5.772 . The Variable of Convenience to Transport Performance is 2,635, the Variable of Urbanity to Transport Performance is 5,423 and the timeliness variable to Transport Performance is 6,501 greater than the t-table value (1.96).

From the results of this study, it shows that reliability significantly influences the performance of transportation. This can be seen from the R2 value of 0.443 which means that the value indicates that the reliability variable is able to explain the transportation performance variant around $44.30 \%$, then Comfort has a significant effect on transportation performance. Convenience contributed $26.35 \%$, (value R2 $=2.635$ ). The subsdistrict factor influences the 
284| Jurnal Ilmiah Ilmu Administrasi Publik: Jurnal Pemikiran dan Penelitian Administrasi Publik

Volume 1o Number 1, January - June 2020. Page 275-286

transportation performance and contributes $54.23 \%(\mathrm{R} 2=5,423)$. While the timeliness factor significantly influences the transportation performance. Timeliness contributed $60.50 \%(\mathrm{R} 2=$ 6,501). The results of the analysis of the effect are significantly on the performance of transportation, because statistically after checking each statistical value of all> 1.96 .

The rest of the factors that affect the performance of Pete-Pete transportation in Makassar City are influenced by other factors not discussed in this study.

Based on the values of the contribution to the transportation performance obtained, it can be concluded that the punctuality factor has the largest contribution of influence of $60.50 \%$ on the performance of pete-pete transportation. This shows that users of pete-pete transportation in Makassar are generally perceived by users to have punctuality at their destination.

Furthermore, the generosity factor contributes to the performance of pete-pete transportation by $54.23 \%$. The reliability factor contributes to the performance of pete-pete transportation by $44.30 \%$. While the convenience factor has a contribution to the performance of pete-pete transportation in Makassar City by $26.35 \%$

What can be explored more deeply in the results of this study is that the safety factor does not have a significant effect on the performance of pete-pete transportation in Makassar City. The value of the statistical results is 0.078 smaller than $t$ table of 1.96 . The hypothesis which states that there is a security influence has a positive influence on the Transportation Performance, is stated to be rejected.

These results provide an explanation that the perception of transport users on the performance of Pete-Pete transportation in Makassar City, concludes that the safety factor is not a measure for using or assessing pete-pete transportation services in Makassar City.

Although users generally state that the safety factor in travel is in the safe category of pete-pete transportation, users no longer question safety in evaluating the performance of petepete transportation services.

This is also closely related to the results of observations in the field which show that there are still pete-pete transports that are not roadworthy, but are forced to look for passengers in Makassar City because there is no fast transportation other than pete-pete transportation.

In connection with this factor the habit of using pete-pete every day, users assume that pete-pete transportation is more simple, practical and inexpensive as transportation in Makassar City. Safety for luggage in transit, proper interior seating, cleanliness, credibility and speed of the vehicle and how the driver drives the vehicle are not important in determining the performance of pete-pete transportation services in Makassar City.

Although the safety factor is important in the journey, the user considers that this public transportation service besides affordable costs, (Kelurahan), punctuality to destination, comfort in the vehicle, reliability of using pete-pete transport, also because there are no other choices in using services transportation other than pete-pete transportation in Makassar City.

Another reason is that security does not have an effect on transportation performance because pete-pete public transport users are generally used by people who have a weak economy in Makassar City. Generally, they are living on the edge of the city to their destination either to school, workplace, shopping and others, where they use pete-pete transportation for daily needs until they reach their destination. 
Didin Halim, Herman H; Analisis Persepsi Pengguna Terhadap Kinerja Pelayanan Angkutan ... | 285

\section{CONCLUSION}

Based on the formulation of the problem, research objectives, hypothesis testing and discussion of research results, it can be concluded that: 1) The description of user perceptions of the performance of pete-pete public transport shows that the reliability factor is good in terms of travel destination, travel time, and distance traveled in traveling, it was perceived that in general (76.7\%) users carried out routine activities such as from work, from school / campus and from shopping, by choosing pete-pete transportation in Makassar City. This means that pete-pete transportation is still needed for public transportation services in Makassar City. The comfort factor generally always uses (54\%). The safety factor seen from the safety in traveling is in the safe category (85\%). The generosity factor in general the tariff ranges from> Rp. 5,000 (80\%). Factors of timeliness, perceptions of transport users generally stated on time both when riding a vehicle to get to the destination (63\%). 2) There is a positive and significant influence on the reliability factor on the performance of Pete-Pete transportation in Makassar City, with a contribution of $44.30 \%$. 3) There is a positive and significant influence of comfort factor on the performance of Pete-Pete transportation in Makassar City, with a contribution of $26.35 \%$. 4) There is no positive influence on the safety factor on the performance of Pete-Pete transportation in Makassar City, with a contribution of only $0.78 \%$. 5) There is a positive and significant influence of the factor of poverty on the performance of Pete-Pete transportation in Makassar City, with a contribution of 54.23\%. 6) There is a positive and significant influence of the Timeliness factor on the performance of Pete-Pete transportation in Makassar City, with a contribution of $60.50 \%$.

\section{REFERENCES}

Amanda, M. O., Salam, R., \& Saggaf, S. (2017). Pengaruh Supervisi Kepala Sekolah Terhadap Kinerja Guru Di SMK Negeri 1 Bungoro Kabupaten Pangkep. Prosiding Seminar Nasional Himpunan Sarjana Ilmu-Ilmu Sosial, 2, 149-154.

Creswell, J. W. (2013). Research Design: Qualitative Approach, Quantitative and Mixed. Yogyakarta: Student Library.

Creswell, J. W., \& Creswell, J. D. (2017). Research design: Qualitative, quantitative, and mixed methods approaches. Sage publications.

Dahlan, D., Hasim, D., \& Hamdan, H. (2017). Pengaruh Manajemen Sumber Daya Manusia dan Budaya Organisasi Terhadap Kualitas Pelayanan Pada Kantor Kecamatan Tamalate Kota Makassar. Jurnal Ad'ministrare, 4(2), 69-75.

Fazakis, N., Karlos, S., Kotsiantis, S., \& Sgarbas, K. (2019). A multi-scheme semi-supervised regression approach. Pattern Recognition Letters, 125, 758-765. https://doi.org/https://doi.org/10.1016/j.patrec.2019.07.022

García Osma, B., Mora, A., \& Porcuna-Enguix, L. (2019). Prudential supervisors' independence and income smoothing in European banks. Journal of Banking \& Finance, 102, 156-176. 
286 Jurnal Ilmiah Ilmu Administrasi Publik: Jurnal Pemikiran dan Penelitian Administrasi Publik Volume 1o Number 1, January - June 2020. Page 275-286

https://doi.org/https://doi.org/10.1016/j.jbankfin.2019.03.001

Hentika, N. P., \& Setyowati, E. (2016). Upaya Kementerian Agama Dan Non Government Organization (Ngo) Dalam Memperbaiki Manajemen Masjid Di Kota Malang. Jurnal Ad'ministrare, 3(1), 38-50.

Jamaluddin, J., Salam, R., Yunus, H., \& Akib, H. (2017). Pengaruh budaya organisasi terhadap kinerja pegawai pada dinas pendidikan provinsi sulawesi selatan. Jurnal Ad'ministrare, 4(1), 25-34.

Ju, D., Huang, M., Liu, D., Qin, X., Hu, Q., \& Chen, C. (2019). Supervisory consequences of abusive supervision: An investigation of sense of power, managerial self-efficacy, and task-oriented leadership behavior. Organizational Behavior and Human Decision Processes, 154, 80-95. https://doi.org/https://doi.org/10.1016/j.obhdp.2019.09.003

Khosa, A., Burch, S., Ozdil, E., \& Wilkin, C. (2019). Current issues in PhD supervision of accounting and finance students: Evidence from Australia and New Zealand. The British Accounting Review, 100874. https://doi.org/https://doi.org/10.1016/j.bar.2019.100874

Paksi, Y. E. E., \& Prihartono, E. (2019). Sistem Monitoring Pemakaian Air Pdam Tirta Kencana Kota Samarinda Berbasis Arduino. JIMP-Jurnal Informatika Merdeka Pasuruan, 4(2).

Prasodjo, T. (2019). Knowledge Management: Sustainable Human Resource Development in Public Sector Organizations. Jurnal Ad'ministrare, 6(2), 159-166.

Pristiwaluyo, T., \& Ab Hakim, F. (2019). Pengaruh Kompetensi Kepribadian dan Kompetensi Sosial terhadap Pelaksanaan Supervisi Akademik Pengawas Sekolah Menengah Atas. Jurnal Ad'ministrare, 5(2), 63-76.

Siagian, S. P. (1989). Fungsi-fungsi manajerial. Bina Aksara.

Sufianto, A. (2015). Pengaruh Pengawasan Terhadap Efektifitas Kerja Pegawai Pada Kecamatan Samarinda Kota Di Kota Samarinda.

Suratman, Y. P. (2017). Taksonomi Konflik-Konflik Internal Di Indonesia Sebagai Potensi Perang Proxy (Taxonomy Of Internal Conflicts That Leads Into Proxy War In Indonesia). Jurnal Pertahanan \& Bela Negara, 7(1), 39-52.

Syamsiar, S., Saggaf, M. S., Salam, R., \& Ihsan, S. R. (2018). Implementation Of Supervision On Office Of Community Empowerment And Makassar City Village.

Syukur, M., \& Awaru, O. (2019). Opportunities and Challenges of Organic Agriculture in the Era of Industrial Revolution 4.0 (A Case Study at Bulukumba Regency; South Sulawesi Province). International Conference on Social Science 2019 (ICSS 2019).

Wildana, A., \& Awaru, A. O. T. (2018). Perilaku Akademik Aktivis (Studi Kasus Pada Mahasiswa Fis UNM Yang Aktif di Organisasi Daerah). JURNAL SOSIALISASI, 1-6. 